Boston University School of Law

Scholarly Commons at Boston University School of Law

Faculty Scholarship

$4-2011$

Women and Children Last - The Predictable Effects of Proposed Federal Funding Cuts

Wendy K. Mariner

George J. Annas

Follow this and additional works at: https://scholarship.law.bu.edu/faculty_scholarship

Part of the Health Law and Policy Commons 


\title{
Women and Children Last - The Predictable Effects of Proposed Federal Funding Cuts
}

\author{
George J. Annas, J.D., M.P.H., and Wendy K. Mariner, J.D., M.P.H
}

"W omen and children last" might as well be the refrain of the current U.S. Congress's new health care budget cutters. We have seen similar efforts before. In the mid-1990s, managed care organizations tried to save money by limiting hospitalization benefits for new mothers and their infants to 24 hours after a vaginal delivery and 48 hours after a cesarean section. ${ }^{1}$ As with current Congressional proposals, financial savings were seen as more important than the health of women and children. Because only women get pregnant and give birth, restricting access to reproductive health care is discriminatory on its face and undermines the social and economic gains that women have made in the United States. ${ }^{2}$

Yet there are at least two major reasons why proposals to limit or eliminate federal funding for women's reproductive health services appeal to some politicians. The first is that the primary beneficiaries of those services are low-income women and their children, a group with virtually no political influence and no financial resources with which to fight these cuts. Second, comprehensive reproductive health care includes pregnancy terminations, and although women have a constitutional right to terminate a pregnancy before fetal viability, abortion remains the most contentious issue in U.S. politics. Although attempts to overturn Roe $v$. Wade altogether have been ongoing for almost four decades, current efforts have largely been redirected toward restricting or ending federal funding of abortion and anything that is arguably related to abortion.

This second reason is why President Barack Obama, in his speech about health care reform to a joint session of Congress in September 2009, pledged that "Under our plan, no federal dollars will be used to fund abortion." ${ }^{3}$ It is also why, in order to get final approval of the Affordable Care Act (ACA) in the House of Representatives, the President, in March 2010, agreed to issue an executive order to make it crystal clear that no federal funds under the ACA would be used to fund abortion services (except in the cases of rape, incest, or danger to the life of the pregnant woman) and that this restriction would also specifically apply to community health centers. ${ }^{4}$ The executive order was enough to satisfy Congressman Bart Stupak (D-MI), whose vote and support were needed to pass the ACA. ${ }^{4}$ Stupak's decision was courageous, and he paid for it by not running for reelection. It did not, however, satisfy his coauthor on the anti-abortion Stupak-Pitts amendment, Congressman Joe Pitts (R-PA), who is now in the powerful position of chair of the House Energy and Commerce Subcommittee on Health. Pitts continues to object to current federal funding laws and has proposed enacting legislation to prohibit the federal government from reducing its funding for any hospital that refuses to perform an abortion, even one that is necessary to save a woman's life. Of course, such legislation could not affect the ethical or legal obligations of physicians to provide necessary medical care to their patients, but it is emblematic of efforts to put antiabortion ideology above the lives of women.

On the other hand, provisions that made it into the House budget bill - and are up for negotiation with the Senate - include the total elimination of federal funding for the 4400 Title X clinics (the national family-planning program) that serve only lowincome women, providing them with birth control and screening for sexually transmitted diseases, breast and cervical cancer, and HIV; ending all federal funding of Planned Parenthood and its 102 affiliates, which serve 11 million women per year, $82 \%$ of whom get contraception services; cutting $10 \%$ from the special supplementary nutrition program for women, infants, and children (WIC), which serves 10 million low-income women and their children each month; and cutting $\$ 50$ million from block grants supporting prenatal care for 2.5 million low-income women and health care for 31 million children annually.

The amounts of money saved by these cuts would be trivial, but the damage to the health of lowincome women and children especially from the loss of direct federal funding for food and preventive health care - could be devastating. The proposed cuts are simply cruel. Cutting funding 
to Planned Parenthood makes little health or fiscal sense, because the organization's services are necessary for the health of millions of women who have little access to health care. Planned Parenthood clinics spend approximately $3 \%$ of their budgets on abortion services. (An antiabortion budget cutter could thus justify reducing the organization's federal funding by $3 \%$, but no more - unless the cut was meant to be punitive.) The other cuts, such as those to Title X clinics, are primarily designed to reduce funding for contraception counseling and reproductive health aspects of primary care. There are certainly groups and religions that object to the use of contraception, especially for teenagers. But those who object to abortion should recognize that eliminating these services is incompatible with the health of women and children.

Two years ago, before the current debate over ACA funding, a Guttmacher Institute study concluded that eliminating Title $\mathrm{X}$ clinics (and Medicaid funding for contraception counseling) would result in an additional 860,000 unintended pregnancies and 810,000 abortions per year among lowincome women. ${ }^{5}$ The study also found that from a strictly bud- getary perspective, helping lowincome women prevent pregnancies saved almost $\$ 4$ for every $\$ 1$ spent. ${ }^{5}$ Rational policymakers who oppose abortion and support fiscal restraint should thus also support current federal efforts to reduce unplanned pregnancies.

In a commencement address delivered at Notre Dame University on the 36th anniversary of the Roe v. Wade decision, President Obama reminded his audience that Roe "not only protects women's health and reproductive freedom, but stands for a broader principle: that government should not intrude on our most private family matters." He also said he believed that no matter what one's position on Roe, "we are united in our determination to prevent unintended pregnancies, reduce the need for abortion, and support women and families in the choices they make." To achieve these aims, the President rightly said, "we must work to find common ground to expand access to affordable contraception, accurate health information, and preventive services ... [and] commit ourselves more broadly to ensuring that our daughters have the same rights and opportunities as our sons."

There are no politics like abor- tion politics. But unless the U.S. Senate and the President continue to stand with American women in promoting reproductive health rights as a fundamental part of their health and human rights, these words spoken at Notre Dame will ring hollow, and women will see their rights and their health care eroded rather than improved under the ACA. Political compromise is inevitable, but it should not continue to come primarily at the expense of women's health.

Disclosure forms provided by the authors are available with the full text of this article at NEJM.org.

From the Department of Health Law, Bioethics, and Human Rights, Boston University School of Public Health, Boston.

This article (10.1056/NEJMp1102915) was published on April 6, 2011, at NEJM.org.

1. Annas GJ. Women and children first. N EnglJ Med 1995;333:1647-51.

2. Council on Women and Girls. Women in America: indicators of social and economic well-being. Washington, DC: Executive Office of the President, the White House, March 2011.

3. Annas GJ. Abortion politics and health insurance reform. N Engl J Med 2009;361: 2589-91.

4. Annas GJ. The real pro-life stance: health care reform and abortion funding. $\mathrm{N}$ Engl J Med 2010;362(16):e56.

5. Gold RB, Sonfield A, Richards CL, Frost JJ. Next steps for America's family planning program: leveraging the potential of Medicaid and Title $X$ in an evolving health care system. New York: Guttmacher Institute, 2009.

Copyright (C) 2011 Massachusetts Medical Society.

\title{
Our Bulging Medicine Cabinets - The Other Side of Medication Nonadherence
}

\author{
William H. Shrank, M.D., M.S.H.S.
}

Tast September, the Drug Enforcement Agency, in partnership with local police departments throughout the country, held a "National Prescription Drug TakeBack Day." More than 4000 police departments participated, and in Orange County, Florida, alone, more than 1.5 tons of prescription medications were returned. The point of the initiative was to permit safe disposal of controlled substances, and Americans took the opportunity to dispose of all types of medications that they had amassed in their medicine cabinets. Another such event is scheduled for April 30, 2011. 